\title{
András Szigeti
}

\section{Innovation and Representation in Postmodern Fiction}

"Oh I wish there were some words in the world that were not the words I always hear!"

\section{INTRODUCTION}

\subsection{Legitimation}

Each age and each culture has its very own sources of anxiety. The Greeks feared chaos, the Middle Ages feared the withdrawal of divine benevolence, modernity fears facelessness. The threat of amnesia, the vacuum of lost identity, the uniformity of the crowd and the monotony of custom. The horror of the blank page. This fear explains the irrepressible urge of the modern individual to establish his identity, justify his existence, find his place in the world. It also explains the reflectiveness of our age, its longing for new definitions and new beginnings.

(Post-)modernity ${ }^{2}$ is caught up in a self-perpetuating cycle of selfdefinition and self-legitimation. This is not only its accidental characteristic, but its very essence and raison d'être. "It is not self-evident that an epoch poses itself the problem of its historical legitimacy; just as little is it self-evident that it

\footnotetext{
${ }^{1}$ D. Barthelme: Snow White. p. 6

${ }^{2}$ The problem of defining the relationship of modernity and postmodernity lies beyond the scope of this essay and so does a systematic comparison of postmodernist and modernist fiction. I will, therefore, make the admittedly sweeping generalisation that the central issues in modernity and postmodernity are similar, hence the brackets. Arguably, however, postmodernity articulates its position on these issues in essentially novel ways, this is why I have not used the brackets when going on to discuss innovation in postmodern fiction.
} 
understands itself as an epoch at all." ${ }^{3}$ An understanding of the past as a source of traditions handed down from one generation to another is superseded by 'history' - a chronological account of past events established through 'objective' verification procedures. History in modernity is constructed by critical thought in order to serve as an objective reference point in the process of contemporary selfevaluation and self-legitimation. As Habermas argues, "Modernity can and will no longer borrow the criteria by which it takes its orientation from the models supplied by another epoch; it has to create its normativity out of itself. Modernity sees itself cast back upon itself without any possibility of escape." ${ }^{4}$ Consequently, even the present, the now of modernity itself will become a construct that will be re-examined and re-constructed again and again. "Modernity, in whatever age it appears, cannot exist without a shattering of belief and without discovery of the 'lack of reality' of reality, together with the invention of other realities."

The problem of self-legitimation manifests itself particularly acutely in (post-)modern aesthetics: "...the question of modern aesthetics is not: 'What is beautiful? but 'What is art to be (and what is literature to be)?" 6 The numerous innovative strategies developed in postmodern fictions may be seen as attempts to answer this question in new ways. Postmodern fictions do not break radically with the aesthetics of modernism, inasmuch as self-legitimation continues to be the crucial problem. Yet they are to a very large extent innovative in the ways in which they seek to secure their legitimacy, making use of new artistic strategies to represent an essentially new way of experiencing the world.

${ }^{3}$ H. Blumenberg: Legitimität der Neuzeit. p. 72. Quoted in: J. Habermas: The Philosophical Discourse of Modernity. Twelve Lectures. p. 7

${ }_{5}^{4}$ J. Habermas: The Philosophical Discourse of Modernity. Twelve Lectures. p. 7

5 J.-F. Lyotard: "Answering the Question: What is Postmodernism?" p. 77

${ }^{6}$ J.-F. Lyotard: The Postmodern Explained. Correspondence 1982-1985. pp. 6-7. Or the same question in a somewhat more fortunate wording: "the modern aesthetic question is not 'What is beautiful?' but 'What can be said to be art (and literature)?'” J.-F. Lyotard: Answering the Question: What is Postmodernism? p. 75. It is highly interesting that the same question was posed by Georg Lukács in the opening passage to his Heidelberg Fragments on the Philosophy of Art and Aesthetics as early as the second decade of the twentieth century. By posing the question: "works of art exist - how are they possible? [Mûalkotások léteznekhogyan lehetségesek?]", he had addressed the fundamental question of (post-)modern art even before modernism, let alone postmodernism, would have reached full maturity. cf. G. Lukács: $A$ beidelbergi mûvészetfilozófia és esztétika. p. 15 


\subsection{Outline}

A number of traditional and innovative narrative techniques used by postmodern writers will be discussed in the following essay, in order to investigate the nature and extent of aesthetic innovation in postmodern fiction. I will look in particular at the works of two American and a British author to demonstrate the use of these techniques. Obviously, this limited selection is not meant to stand for all the various movements and directions in contemporary fiction. Nevertheless, the selected writings of John Barth (Lost in the Funhouse), Donald Barthelme (five short stories) and John Fowles (The French Lieutenant's Woman) illustrate important modes of innovation. In addition, these works may be said to occupy distinctly different positions on a scale of varying aesthetic radicalism, ${ }^{7}$ and therefore show that there may be considerable discrepancy in terms of the degree and scope of innovation.

I will adopt the term 'strategy' to label innovative narrative techniques, because it may be quite fruitful to interpret these techniques as aesthetic means serving a certain artistic purpose. Strategies are vehicles of the artistic intention. Furthermore, the term should also express the markedly conscious and calculated use of innovative artistic devices in postmodern fiction. Obviously, innovative strategies are products of a thoroughly creative process, but this does not alter the fact that they are employed in a tendentious and systematic manner. It will be argued that by and large these innovative narrative strategies can be subsumed under two general categories (dominants): transtextuality and metafictionality.

If innovative narrative strategies can be shown to manifest certain patterns and tendencies, then one may speculate that these uniformities indicate a more fundamental and systematic change in the aesthetics of postmodern literature. The analysis of innovative narrative strategies and new dominants in postmodern fiction is in this sense not the end, but the beginning of the enquiry which concerns the changing functions of aesthetic representation in postmodernity. What is the relationship of representing word and represented world? To what extent can postmodern writing be said to be mimetic? How can the postmodern concern with self-legitimation be related to innovation and the changing functions of fictional representation?

There is little sense in trying to find ultimate answers to these questions. The problematic nature of the relationship of representation and reality (word

\footnotetext{
' Such a scale of postmodern fiction from the most radical modes of innovation to the most conservative is, for instance, set up in: P. Waugh: Metafiction. pp. 115-150
} 
and world, sign and signified) lies at the very heart of the whole philosophical debate about postmodernity. Any attempt to present what is supposed to be the exact description of the relationship of representing and represented would be begging the question, namely the question concerning reality and its true representations. Nevertheless, it may be possible to find relevant models of the relationship of reality and representation. Postmodern fictions may provide us exactly with such models. They seem to have developed (a) new model(s) of how reality is experienced and constructed, experience is represented and constructs deconstructed.

In the conclusion, therefore, I will return to the crucial problem of selflegitimation in postmodernity. I will try to explain how the pursuit of selflegitmation and authenticity yields innovation and why innovation in postmodern fiction must fundamentally alter the status and function of fictional representation.

\section{INNOVATION AND REPRESENTATION}

\subsection{Innovation and tradition in postmodern literature}

"What's new? Nothing ... Conventional startling opener." 8 The paranoid preoccupation of postmodern literature with the threat of crisis and aesthetic impotence is perhaps unparalleled in the history of literature. One senses an omnipresent fear of there being nothing new to say and no new ways to say it, an exhaustion of all possible means of literary innovation. The terror of the blank page. The paradigmatic moment of postmodern literature is the author sitting at his desk, pen in hand and nothing to fill the piece of paper in front of him. "Everything's been said already, over and over; I'm as sick of this as you are; there is nothing to say. Say nothing." And then again... The paradigmatic moment of postmodern literature is not the author sitting at his desk, pen in hand and nothing to fill the piece of paper in front of him: it is rather the author sitting at his desk, writing about the moment of an author sitting at his desk etcetera. Postmodern literature may be the "literature of exhaustion, ${ }^{, 10}$ but it is still literature in the full sense of the word. Whatever the particular obsessions and

\footnotetext{
${ }^{8}$ J. Barth: "Title" in: Lost in the Funhouse. p. 105

${ }^{9}$ Ibid, p. 105

${ }^{10}$ J. Barth: "The Literature of Exhaustion." pp. 29-34
} 
paranoias of this literary period may be, what matters is that they are being articulated continuously and constructively in works of fiction.

In other words, the contemporary sense of aesthetic and existential insecurity is expressed in definite and positively identifiable forms in postmodern literature. What is more, these forms share a number of similar features, therefore, they lend themselves to description and categorisation by a poetics of postmodern literature. The first task of such a postmodern poetics is to describe these literary forms as constituents of an organised system. Secondly, to explain how and why this system differs from those of previous literary epochs. Obviously, there will be no attempt made in the following to develop an independent poetics of postmodern literature. By analysing the works of the three authors selected (Barth, Barthelme and Fowles), I will only offer a few examples from the array of artistic devices constituting the organised system of contemporary literature.

One should, however, never lose sight of the fact that literary innovation is a continuous process: the supersession of one literary period by another involves a reshuffling of the hierarchy of the constitutive elements of the old literary system and a redefinition of the relationship between these elements, rather than 'creation out of nothing'. The concept of the dominant developed by the Russian formalist school is often cited to describe this dynamics of literary innovation: " "The dominant may be defined as the focusing component of a work of art: it rules, determines, and transforms the remaining components. It is the dominant which guarantees the integrity of the structure... a poetic work [is] a structured system, a regularly ordered hierarchical set of artistic devices. Poetic evolution is a shift in this hierarchy." 12

I will argue in the following that the two features that seem to be the 'focusing components' of postmodern fiction as well as the 'focusing components' of individual postmodern works are metafictionality and transtextuality. It is, of course, not the case that fictional works produced in previous literary periods would be entirely devoid of metafictional or transtextual features. Sterne's Tristram Shandy is, for instance, a characteristically metafictional novel, and transtextual practices, such as parody, have already reached highly developed forms long before the dawn of postmodernity in Cervantes' Don Quixote and Fielding's Tom Jones (not to mention parody in Greek antiquity). “...[The] term 'metafiction' might be new, the practice is as old (if not older) than the novel

${ }^{11}$ cf. P. Waugh: Metafiction and B. McHale: Postmodernist Fiction.

${ }^{12}$ Roman Jakobson: "The dominant." Quoted in: B. McHale: Postmodernist Fiction. p. 6 
itself... metafiction is a tendency or function inherent in all novels," ${ }^{13}$ writes Patricia Waugh on metafictionality. The same point can be made with regard to the uninterrupted literary tradition of transtextual practices. ${ }^{14}$ In postmodern works of fiction, however, these two features assume an absolutely central significance: they seem to underlie all of the innovative literary strategies employed by postmodern authors. To put it another way, the direction of innovation is fundamentally determined by these two pivotal aspects in postmodern literature.

"Plush upholstery prickles uncomfortably through gabardine slacks in the July sun. The function of the beginning of a story is to introduce the principal characters, establish their initial relationships, set the scene for the main action, expose the background of the situation if necessary, plant motifs and foreshadowings where appropriate, and initiate the first complication or whatever of the 'rising action'. Actually, if one imagines a story called 'The Funhouse' or 'Lost in the Funhouse,' the details of the drive to Ocean City don't seem especially relevant." ${ }^{15}$

Coming across such a passage in John Barth's Lost in the Funbouse, the reader will inevitably be stricken by the feeling of being exposed to something new, of being addressed in a novel way: the blunt arrogance and directness of the authorial intrusion in the above quote is no doubt unusual.

So is the frequency of such authorial intrusions and self-reflexive interruptions, for as Patricia Waugh points out: "[in Lost in the Funhouse] almost every sentence is undermined and exposed as fictional." ${ }^{16}$ In fact, almost all postmodern texts contain the conspicuous metafictional tendency observable in Barth's story. The explicitness and intensity of this tendency may differ, but the fact remains that postmodern texts display an unprecedented consciousness of their fictionality. They persistently 'lay bare the devices of art' and remind the reader of their own fictional status.

\footnotetext{
${ }^{13}$ P. Waugh: Metafiction. p. 5

${ }^{14}$ cf. G. Genette: Palimpseste. Die Literatur auf zweiter Stufe. At the time of writing, Genette's book was not yet available in English. I will, therefore, invariably refer to the German edition when giving page numbers. All translations are mine.

${ }^{15}$ J. Barth: "Lost in the Funhouse." in: Lost in the Funbouse. p. 77

${ }^{16}$ P. Waugh: Metafiction. p. 95
} 
Once again, pre-modern and modernist texts have also often shown some explicit awareness of their fictionality, but this awareness has never been a constitutive, 'focusing component' of these texts. By contrast, metafictionality is present at all levels of postmodern fiction: from the minutest word-play or typological allusion to the general structuring of the text, the presentation of characters and the construction of fictional time and space. The reader cannot help participating in an incessant to and fro movement between fiction and metafiction. Something presented in the text - whether a description, a character or an event - will be immediately questioned, undermined and even revoked as it is made clear to the reader that these fictional objects only exist in and through the act of presentation.

The other ubiquitous feature, 'focusing component' of postmodern texts is their transtextuality. In a narrower sense, this means that they continuously refer to, quote, paraphrase and parody earlier literary texts. In Gérard Genette's words, postmodern texts display a very strong textual transcendence, a presence of all those textual elements "... that establish an explicit or hidden relationship between one text and another." 17 Needless to say, literary works have always drawn very strongly upon one another. The etymology of the word parody suffices alone as evidence that transtextual practices are as old as literature itself. ${ }^{18}$

Postmodern literary strategies, however, exploit the textual transcendence of texts in radically new ways. First of all, one encounters a series of formal and stylistic innovations. Postmodern fictions have refreshed literary forms and genres, such as allegory and the picaresque novel that were neglected in previous literary periods. They have also successfully incorporated certain topoi and techniques of popular genres, such as science fiction and pornographic literature, previously held to be 'below' the standards of high literature. Moreover, postmodern fiction has generally defined itself "on the basis of its rejection of norms and patterns that originate from nineteenth-century romanticism and realism as well as on the basis of its return to 'pre-modern' (or pre-postmodern) literary techniques of the sixteenth, seventeenth and eighteenth centuries." ${ }^{19}$

Even more important is the fact, however, that postmodern authors radically alter former conventions of transtextuality. They reject the traditional

\footnotetext{
${ }^{17}$ G. Genette: Palimpseste. p. 9

${ }^{18}$ Ibid, pp. 21-39

${ }^{19}$ Ibid, pp. 286
} 
transtextual etiquette, conventional ways of quoting, imitating and parodying other texts. It is not only that the texts they quote and imitate differ from those quoted and imitated by other authors before them. The key difference (and this a point not mentioned by Genette in the quote above) lies in how they quote, parody and insinuate and why they quote, parody and insinuate. What I hope to demonstrate in the following is that this difference is significant enough to make transtextuality one of the distinguishing marks of postmodern texts. In short, what lies ahead is to show that these transtextual practices-alongside their metafictional companions-are the ones that really make postmodern texts different.

\subsection{Innovative narrative strategies in Barth, Fowles and Barthelme}

Innovative strategies may be used at different levels of the literary work. Some innovative strategies affect the overall structure of the text or the description of characters, whereas others operate at the level of vocabulary or typographical presentation. The following analysis will primarily concentrate on establishing relevant correspondences between the innovative strategies employed by these three authors. Accordingly, there will be no effort made here to set up an exact hierarchy or provide an exhaustive list of narrative strategies at all possible levels of postmodern fictional works. What is of much greater importance is the point made in the introduction, namely that similar narrative strategies may be used in a more or less innovative fashion, so the selected texts may be said to occupy different positions on an imaginary scale of aesthetic radicalism. I will argue that John Fowles' novel could be located nearest to the 'conservative' pole, John Barth would be found somewhere in the middle and Donald Barthelme fairly close to the other, 'revolutionary' end of this scale.

Certain critics tend to view the new techniques used by postmodern authors as independent entities. Thus, for example, Edgar H. Knapp talks about the dialectic relationship of "technical obtrusions and the rest of the story" in Barth's Lost in the Funhouse. ${ }^{20}$ It seems meaningless, however, to assume the separate existence of technical innovations from that of 'the rest of the story.' Innovative narrative strategies are not somehow imposed on an otherwise neutral text, on the contrary, these strategies constitute the text. They are interwoven in intricate ways to make up the 'texture' of what is presented.

${ }^{20}$ Edgar H. Knapp: "Found in the Barthhouse: Novelist as Savior." in: Joseph J. Waldmeir (ed.): Critical Essays on John Barth. 
It also follows from this that narrative strategies, innovative as well as traditional, almost always occur in combination. Theoretical considerations may justify a separate analysis - it may be perfectly justifiable to concentrate on the innovative rhyming pattern of a certain poem, should that be the most remarkable novelty presented by that poem. Nevertheless, the following theoretical classification of narrative strategies should not obscure the fact that the works discussed always constitute in the end an irreducible and organic unity.

I will discuss innovative narrative strategies used by Barth, Barthelme and Fowles under four separate headings. The first two will be devoted to overtly metafictional and overtly transtextual strategies, respectively. These present fewer theoretical difficulties because they can be easily related to the dominants of postmodern literature. It will also be easier to determine the direction and scope of literary innovation in these cases. At the same time, it seems to me that it is exactly the innovative use of strategies in the other two categories that proves the general claim that metafictionality and transtextuality can be seen as the 'focusing components' of the poetics of postmodern literature. The fact that even these postmodern literary strategies, not explicitly metafictional or transtextual, can be shown to have been informed by metafictional and transtextual tendencies is the most important evidence of the 'dominance' of metafictionality and transtextuality.

\subsubsection{Overtly metafictional strategies}

"Metafiction is a term given to fictional writing which self-consciously and systematically draws attention to its status as an artefact in order to pose questions about the relationship between fiction and reality... Metafictional novels tend to be constructed on the principle of sustained opposition: the construction of a fictional illusion (as in traditional realism) and the laying bare of that illusion."21 Metafictionality is a tendency rather than any clearly identifiable literary pattern. This tendency is by definition inherent in all novels, but it only acquires central and systematic importance in postmodern works of fiction. Here metafictionality is not limited to certain levels or areas of literary works, but affects each level and the general organisation of the text as well. It may be useful, therefore, to distinguish between overt and covert forms of metafictionality. ${ }^{22}$ In the present

\footnotetext{
${ }^{21}$ P. Waugh: Metafiction. p. 2, p. 6

${ }^{22} \mathrm{~L}$. Hutcheon distinguished between overt (thematised) and covert (structuralised, internalised, actualised) forms of textual narcissism in her work on metafiction (Narcissistic Narrative:
} 
section, I will concentrate exclusively on explicitly metafictional strategies figuring in the selected texts. These strategies are self-conscious comments or reflections on the fictionality of the very text in which these comments and reflections are made.

"Under the broadwalk, matchbook covers, grainy other things. What is the story's theme? Ambrose is ill. He perspires in the dark passages; candied apples-on-a-stick, delicious looking, disappointing to eat..." ${ }^{23}$

John Barth's Lost in the Funhouse has been referred to as the paradigmatic example of self-conscious fiction: "the most noticed, most prototypical, and most overt kind of metafiction." ${ }^{24}$ The story is full of similar comments, reflecting on the narrative developments just described, considering alternative ways to continue, offering parallel characterisations of the same figure. Moreover, one can identify an even more saliently metafictional type of authorial intrusion in which the author criticises himself for continuously 'going off at a tangent', thus failing to develop the story according to the standard ways of writing fiction.

"We should be much farther along than we are; something has gone wrong; not much of this preliminary rambling seems relevant.,"25

These intrusions could even be called meta-metafictional strategies, since they are in effect comments on the metafictional, excessively reflective character of the text.

It is important to notice the abruptness of the juxtaposition of such explicit metafictional intrusions with sentences or passages that could not only figure in any realistic short story, but are even conspicuously flat and commonplace. Sudden juxtaposition of this kind would be inconceivable in Tristram Shandy or Don Quixote, the classic forerunners of postmodern metafiction. The brusqueness of the shifts creates a tension between the pieces of text placed side by side. Further examples taken from the texts will also testify

The Metafictional Paradox. New York: Methuen. 1984.) This distinction is then taken over and elaborated by S. E. Luzen in her "Notes on Metafiction: Every Essay Has a Title." in: Larry McCaffery (ed.): Postmodern Fiction: A Bio-Bibliographical Guide. pp. 93-116.

${ }^{23} \mathrm{~J}$. Barth: "Lost in the Funhouse" [henceforth LiF]. p. 79. [italics mine!]

${ }^{24}$ S. E. Luzen: Notes on Metafiction. pp. $94-95$

${ }^{25}$ LiF, p. 79 
how this radical collage technique foregrounds the fictional status of fiction and so stresses the division between representing word and represented world.

"I do not know. This story I am telling is all imagination. These characters I create never existed outside my own mind." ${ }^{26}$

This authorial intrusion in John Fowles' novel The French Lieutenant's Woman explicitly declares the fictionality of his characters and can therefore be classified as a metafictional strategy as well. It clearly tells of the author's intention to destroy that mutual agreement entered into by writers and readers of realist works of fiction. The terms of this 'realist' contract stated that the writer will respect the principle of verisimilitude in every possible way, offer insight into the innermost thoughts of his or her characters and provide access to places barred from other mortals, if the reader is also ready on his or her part to suspend the knowledge that what he is reading is after all: only fiction.

At a later stage in the novel the 'author' even enters the fictional world:

"I see this with particular clarity on the face, only too familiar to me, of the bearded man who stares at Charles. And I will keep the pretence no longer. Now the question I am asking, as I stare at Charles..." ${ }^{27}$

The bearded man is, of course, the 'author' himself just caught in the act of framebreaking. He breaks the frame around his fictional world by entering into it. In a sense, this metafictional strategy may seem more radical than those employed by John Barth in Lost in the Funhouse. It should be noted, however, that the overt metafictional strategies used by Fowles are always well prepared and motivated. Jarring shifts from the metafictional discourse to the fictional and back, often favoured by Barth, are avoided in the French Lieutenant's Woman. Fowles' explicit acknowledgement of the fictionality of his text notwithstanding, the introduction of the 'author' into the fictional work "far from abolishing the frame [of the fictional work] merely widens it to include the author as a fictional character." 28

It is remarkable that the five short stories by Donald Barthelme contain very few such overt metafictional intrusions. All the more surprising, as Barthelme's texts

\footnotetext{
${ }^{26} \mathrm{~J}$. Fowles: The French Lieutenant's Woman [henceforth FLW]. p. 97

${ }^{27}$ Ibid, p. 389

${ }^{28}$ B. McHale: Postmodernist Fiction. p. 198
} 
are thoroughly self-conscious and self-contained. That the written text is also an artefact is emphasised in manifold ways. Barthelme can hardly be said to respect the realist 'contract' in any way. It seems to be the case, however, that the metafictional tendency usually operates at deeper or more general levels of his texts. He does construct a 'fictional illusion' and then 'lays this illusion bare' (see Waugh's definition of metafiction above), but construction and deconstruction is more often effected by linguistic means.

Consider the first few lines of Sentence:

"Or a long sentence moving at a certain pace down the page aiming for the bottom - if not the bottom of this page then of some other page where it can rest, or stop for a moment to think about the questions raised by its own (temporary) existence, which ends when the page is turned..., ${ }^{29}$

Although "if not the bottom of this page" [my italics] is an obvious metafictional comment, but then, as if the sentence took off and assumed a completely selfcontained existence. One could almost place a truly explicit metafictional phrase before the beginning of the text, something like 'and then I said to myself the short story I will write will either consist of short and snappy sentences..."or a long sentence moving at a certain pace down the page" etc.' - but it is exactly the absence of such a phrase that make the text appear to be 'beyond' the explicitly metafictional level.

\subsubsection{Overtly transtextual strategies}

The most obvious transtextual strategy is when another literary or non-literary text is quoted, plagiarised, paraphrased or directly referred to. Gérard Genette gives the generic name intertextuality to this kind of transtextual relationship between two texts. "I will define [intertextuality]... as a relationship in which two or more texts are simultaneously present. Precisely speaking, this involves in most cases the actual appearance of one text in another." ${ }^{30}$ Stereotypical characterisations of postmodern innovation in postmodern literature tend to concentrate exclusively on the growing significance of intertextuality in postmodern texts. Undoubtedly, all of the texts discussed here are full of such

\footnotetext{
${ }^{29}$ Donald Barthelme: "Sentence." in: Forty Stories. p. 157

${ }^{30}$ G. Genette: Palimpseste. p. 10
} 
direct references or at least allusions to other texts, but a closer look at them should also reveal that the so-called 'eclecticism' of postmodern works is based on more fundamental changes in postmodern literature.

Intertextual strategies can also be used with a different degree of radicalism. Each chapter of The French Lieutenant's Woman is headed by one or more quotations. The novel contains countless references or allusions to other literary and non-literary texts. The protagonist's manservant is called Sam, a clear and acknowledged allusion to Dickens' Pickwick Papers. There are constant references to Darwin's The Origins of Species on both the diegetic and the narrative level, ${ }^{31}$ relevant aspects of Thomas Hardy's life are discussed.

It is important to note, however, that the intertextual presence of other texts in Fowles' work are also well motivated and can be harmonised with the fictional world of the story. Even at their most provoking (reference to Alain Robbe-Grillet and Roland Barthes ${ }^{32}$ in a novel set in Victorian times), they only serve to heighten and not to undermine the plausibility of the fictional world. Through the deliberate anachronism of some of the explicit intertextual references, Fowles makes it clear to the reader that his intention was to present a Victorian story, but to present it from a contemporary perspective. Paradoxical and unconventional narrative strategies are used because the story is to be relevant today. Nevertheless, Fowles never seems to doubt that it is possible to reconstruct our past in authentic ways.

By comparison, direct intertextual references occur more infrequently in Lost in the Funbouse and the five short stories by Donald Barthelme. When they occur, their function is to amplify the effect of other transtextual or metafictional strategies:

Having to pause for a full hour almost within sound of the breakers was difficult for Peter and Ambrose when they were younger; even at their present age it was not easy to keep their anticipation, stimulated by the briny spume, from turning into short temper. The Irish author James

\footnotetext{
${ }^{31}$ i.e. in the story itself as well as in citations and references made by the author. See G. Genette's definition of these terms: "I... use the word story for the signified or narrative content... and the word narrative for the signifier, statement, discourse, or narrative text itself... With the same meaning ['story'], I will also use the term diegesis..." G. Genette: Narrative ${ }^{32}$ FLW, p. 97 Discourse. p. 27
} 
Joyce, in his unusual novel entitled Ulysses, now available in this country, uses the adjective snot-green and scrotum-tightening to describe the sea. ${ }^{33}$

In contrast to the quotations from Victorian works in the French Lieutenant's Woman, the reference to Ulysses in this context does not serve here to highlight the connection between the text and Joyce's work. Nor is it meant to increase the plausibility of the fictional world by incorporating a real document from the time of the story. By referring to Joyce's description of the sea, Barth presents rather an alternative of his own description in the previous sentence. Whereas Fowles used Victorian documents to back up the realistic effect of his own descriptions and characterisations, Barth employs an intertextual strategy to flaunt the fictional status of his text by providing two stylistically opposing descriptions of the same object in consecutive sentences.

This passage is, therefore, another good example of Barth's (and Barthelme's) collage technique. His change of register is as jarring as possible which significantly intensifies the tension between the two juxtaposed elements. The reader is aggressively confronted with the fact that the description of an object is the function of rhetorical and stylistic patterns. In other words, the description is not inherent in the object described, representation is always the result of a linguistic and textual construction process.

A general reason for the relatively smaller frequency of direct intertextual references, quotations and allusion in the works by John Barth and Donald Barthelme is that other overtly transtextual (but not intertextual) strategies play a more significant role in their texts. The two most important of these is the borrowing of topoi from popular literature and parody.

In metafiction [and postmodern fiction in general], though, writers experiment more commonly with the formulaic motifs of popular literary traditions which have often passed into cinematic forms of representation in the twentieth century: science fiction, ghost stories, westerns, detective stories, popular romance. ${ }^{34}$

${ }^{33} L i F$, p. 74

${ }^{34}$ P. Waugh: Metafiction. p. 81 
There are numerous examples of the use of this innovative strategy in the works of both Barth and Barthelme, but once again, it is worth noting how differently they make use of this strategy in their texts.

The word fuck suggests suction and/or flatulence. Mother and Father; grandmothers and grandfathers on both sides; great-grandmothers and great-grandfathers on four sides, et cetera. Count a generation as thirty years: in approximately the year when Lord Baltimore was granted charter to the province of Maryland by Charles I, five hundred twelve women - English, Welsh, Bavarian, Swiss - of every class and character, received into themselves the penises the intromittent organs of five hundred twelve men, ditto, in every circumstance and posture, to conceive the five hundred twelve ancestors of the two hundred fifty-six ancestors of the et cetera et cetera et cetera et cetera et cetera et cetera et cetera of the author, of the narrator, of this story, Lost in the Funbouse ${ }^{35}$

Lost in the Funhouse is conspicuously rich in such erotic allusions. The most salient feature of these passages is their deliberate unsubtlety. They play with motifs from erotic cinema and popular literature without trying to accommodate these to the stylistic standards of 'high literature'. On the contrary, such 'clips' are placed side by side with the most elevated and poetic segments. This, of course, undercuts both registers.

An even more obvious illustration of this technique is offered in excerpts where the author refers to bodily functions or deliberately tries to provoke disgust.

Funhouses need men's and ladies' room at intervals. Others perhaps have also vomited in corners and corridors; may even had bowel movements liable to be stepped in in the dark. ${ }^{36}$

One can observe a fundamental ambiguity in the presentation of such passages. Naturalistic details are always described only to be undermined and revoked again in the same passage. They are de-represented through typographical, linguistic or metafictional means. Thus, in the first quotation, the deliberate linguistic clumsiness of the whole description, the several 'et cetera', 'ditto' and the

${ }^{35}$ LiF, p. 80

${ }^{36} \mathrm{LiF}$, pp. $79-80$ 
unpunctuated repetition of 'the penises the intromittent organs' interferes with the blunt naturalistic effect. A similar deconstruction of the naturalistic presentation is achieved through a deliberately awkward repetition of the preposition "stepped in in the dark" in the second quotation.

Brian McHale claims that

[postmodern works of fiction] often draw on the repertoires of peripheral or sub-literary genres - thrillers, gothic horror, pornography, cinematic or televised melodrama and farce, and so on. The aim of such sensationalism is to lure the reader into making an emotional investment in the sequence under erasure, typically by arousing his or her anxieties, fascination with the taboo, or prurient interests. Having become 'involved' in the representation, the reader thus resents it when the representation is de-represented, erased. ${ }^{37}$

This de-representation, says McHale, increases the ontological instability of the presented world and calls the readers' attention to the different ontological status of representing and represented.

This dialectic of representation and de-representation is not specific to the use of vulgar and popular forms in postmodern fiction. It is important to note that the same dialectic is at work when other metafictional or transtextual narrative strategies are used. Innovative strategies of postmodern fiction undermine the status and question the authenticity of both the representing word and represented world by intensifying their opposition. $\mathrm{McHale}$ argues that this opposition is of an ontological nature and sees innovative narrative strategies as artistic devices serving to foreground this ontological opposition. Arguably, this interpretation views the relationship of representing and represented in postmodern fiction too much as a static and ontologically absolute opposition. I will try to make a case in the third, concluding chapter for a more dynamic understanding of the same relationship.

What has been said about the idiosyncratic use of overtly metafictional strategies in Barthelme's short stories can more or less be repeated with respect to the function of overtly transtextual strategies in his texts. These display a very intense consciousness of their own textuality, as well as a consciousness of being related to other literary texts through the great structuralist 'network of literature'. Yet,

${ }^{37}$ B. McHale: Postmodernist Fiction. p. 102 
once again, the transtextual tendency usually operates at deeper or more general levels.

Barthelme deliberately maintains a sense of indeterminacy: some passages or even entire stories are often strongly reminiscent of other texts, but it is never quite possible to determine what exactly these texts are. Concerning the Bodyguard, for example, plays with the language and motifs of cheap crime stories, journalistic reports and political literature, but ultimately, the text does not imitate a specific book, author or even any of the aforementioned genres as such. Concerning the Bodyguard is rather a simultaneous reconstruction and deconstruction of the discourse underlying all of these genres. Any number of stories could be developed from the situations sketched by Barthelme, but none is actually developed. There is a great deal of information supplied, almost too much, but all this information is immediately and thoroughly 'insubstantiated' by the question mark at the end of every sentence. The sense of indeterminacy thus achieved has been most concisely described by Barthelme himself in Snow White: "...matter which presents itself as not wholly relevant (or indeed, at all relevant) but which, carefully attended to, can supply a kind of 'sense' of what is going on. This 'sense' is not to be obtained by reading between the lines (for there is nothing there in those white spaces) but by reading the lines themselves..." ${ }^{38}$

Today Goethe inveighed against certain critics who had, he said, completely misunderstood Lessing. He spoke movingly about how such obtuseness had partially embittered Lessing's last years, and speculated that it was because Lessing was both critic and dramatist that the attacks had been of more than usual ferocity. Critics, Goethe said, are the cracked mirror in the grand ballroom of the creative spirit. No, I said, they were, rather, the extra baggage on the great cabriolet of conceptual progress. 'Eckermann,' said Goethe, 'shut up. ${ }^{39}$

Parody has played such an important role in postmodern fiction and been used in so many innovative ways that it can safely be said that no postmodern work is entirely free of parodic elements. The French Lieutenant's Woman is, of course, an obvious parody of traditional nineteenth century novels. Lost in the Funhouse has been referred to as an "elaborate parody, revival, and refutation of Joyce's

\footnotetext{
${ }^{38}$ D. Barthelme: Snow White. p. 106

${ }^{39}$ D. Barthelme: "Conversations with Goethe." in: Forty Stories. p. 67
} 
masterpiece, A Portrait of the Artist as a Young Man." ${ }^{40}$ An exhaustive list of all the parodic narrative strategies in the works analysed here would be beyond the scope of the present work. I will, therefore, only discuss the innovative use of parody in Barthelme's Conversations with Goethe. This work, a representative of the most radical form of postmodern parody, is an excellent example of how traditional literary genres, such as parody, have been transformed by postmodern authors.

Let us then compare Barthelme's Conversations with Goethe with Thomas Mann's Lotte in Weimar. ${ }^{41}$ Thomas Mann's novel is an ironic and playful exercise of the imagination, where the source of Mann's gentle parody is the contrast of the tragic atmosphere and passionate protagonist of Goethe's Werther to the actual serenity and comfort of Goethe's life in Weimar. Despite the fictitiousness of the situation - Goethe is visited by Charlotte Buff, his one-time beloved and model for the heroine of Goethe's novel - Thomas Mann thoroughly respects the principle of historical and aesthetic verisimilitude: whatever is uttered by Mann's characters could have been said by Goethe, Charlotte Buff or Riemer (Goethe's secretary and travel companion at the time), and though unlikely, such an encounter could have taken place.

By contrast, one can hardly imagine Goethe and Eckermann leading the kind of conversation reported by Barthelme. The source of Barthelme's rather ungentle parody is in the main linguistic (rather than situational), its object being the respectful tone of literary biographies and recorded conversations. Barthelme's parody is self-contained, it does not have a theme like Mann's Lotte - youthful passion, the inevitable compromises of age, romantic ideals mellowing into classic tranquillity - it is aimed to imitate and deconstruct a certain type of discourse.

Furthermore, Barthelme's text is an illustrative example of the postmodern handling of the principle of verisimilitude. Dates given at the beginning of each entry are indeed from the time when Eckermann acted as Goethe's secretary, the general form of Barthelme's conversations at least approximate those recorded and published by Eckermann himself, Goethe may well have made a similar remark on Lessing, but the aphoristic style of the conversations is hilariously exaggerated throughout the entire short story. Finally,

\footnotetext{
${ }^{40}$ Michael Hinden: "Lost in the Funhouse: Barth's Use of the Recent Past." in: Joseph J. Waldmeir (ed.): Critical Essays on John Barth. p. 191

${ }^{41}$ This comparison is all the more relevant, since Mann's Lotte in Weimar is itself an explicitly transtextual text. G. Genette calls it a 'supplement' to Goethe's Leiden des jungen Werther. cf. Genette: Palimpseste. pp. 281-283
} 
the flagrant violation of verisimilitude in the last line - surely, Goethe never told Eckermann to 'shut up' - drives home the linguistic comedy through an abrupt change of register.

Innovative strategies employed by Barthelme in Conversations with Goethe, such as the manipulation of the principle of verisimilitude or the abrupt change of register, demonstrate how parody, a traditional transtextual form, is transformed to serve typically postmodern ends. Unlike Thomas Mann's Lotte, Barthelme's text has nothing to say about what the real Goethe or the real Eckermann may have been like. Barthelme concentrates exclusively on formal aspects of a certain type of literary discourse (represented here by Eckermann's Conversations). ${ }^{42}$

The parodic effect is achieved through the re-contextualisation of the figures, structural patterns and linguistic conventions of the target text. What is new about postmodern parody is that this re-contextualisation also exposes the discursive and rhetorical machinery of the parodying text. The two discourses of parodying and parodied text will be placed side by side at each other's expense, they mutually undermine each other. The transferring of various linguistic and textual features of the target text into the new context of the parodying text will automatically expose the textuality of the parodying (con-)text as well.

The same mechanism underlies the use of other innovative transtextual strategies in postmodern fiction, including the incorporation of popular forms or the revival of previously neglected literary genres. Postmodern fictions put the structuralist view of the history of literature into practice, and treat the body of literary tradition as an intricate 'network of texts'. Overt transtextual strategies quotation, imitation and parody - foreground the inevitable textuality of all fictional works, and this always includes not only the text that is being quoted, imitated or parodied, but also that which quotes, imitates and parodies.

Overt metafictional and transtextual strategies discussed in these two sections constitute only a part of the innovative narrative strategies used in postmodern fiction. What is at issue now is whether other innovative strategies in the works analysed here can also be described in terms of a wider definition of metafictionality and transtextuality. In the following, I will not only give a positive answer to this question, but also claim that covert metafictional and

\footnotetext{
${ }^{42}$ Consider Susan Stewart's comment on parody: what has been a 'matter of course' becomes a 'matter of discourse'. Quoted in: P. Waugh: Metafiction. p. 68.
} 
transtextual strategies are simply more radical forms of metafictionality and transtextuality. They radicalise metafictional and transtextual tendencies by transferring these to more general levels of the literary work.

\subsubsection{Structural strategies}

With some simplification one could say that narrative strategies forming the subject-matter of this and the following chapters affect more fundamental or comprehensive aspects of the literary work than those discussed until now. Overtly metafictional comments may occur in a work that in every other respect adheres to the conventions of nineteenth-century realism. Transtextual references, allusions and quotations would also be perfectly conceivable in such a work. Up to this point, therefore, the originality of postmodern fiction has still been more a matter of quantity than of quality. In other words, what has distinguished postmodern works so far has been the unprecedentedly high number of openly metafictional or transtextual strategies. The innovative strategies to be considered in the following, however, could hardly occur in a realist novel. They operate at basic structural and linguistic levels of postmodern fiction.

Given the wide scope of these strategies, it will also be increasingly difficult to separate those that can be associated with the metafictional dominant of postmodern poetics from those that seem to be more related to the transtextual dominant. For the sake of greater transparency, however, I will draw a clear and somewhat arbitrary line between innovative strategies that target the structure and those that target the language of fiction. On the whole, structural innovations seem to be emphasising the fictional status of the literary text, and can therefore be described in terms of the metafictional dominant, whereas linguistic innovations focus more on the textuality of the text, and can therefore be connected to the transtextual dominant of postmodern literature.

"Fictional writing matches an imaginatively constructed fictional object with a general class of possible real objects. ${ }^{43}$ In terms of the 'realist' contract between the 'author' and the 'reader', the latter will suspend his or her knowledge that the fictional object has a different ontological status, and so strictly speaking can never correspond to any member of any class of real objects. Postmodernist metafictional strategies expose precisely the different ontological status of the fictional object by foregrounding the ways in which these objects are constructed

${ }^{43}$ P. Waugh: Metafiction. p. 105 
in fictional representation. The 'realist' contract is cancelled. Fiction still (re)presents, but foregrounds simultaneously the fictionality of the objects (re)presented as well. The more realistically a fictional object is presented, the more ostentatiously its fictionality will be flaunted.

Uncle Karl tapped his cigar ash out the ventilator window some particles were sucked by the slipstream back into the car through the rear window on the passenger side. ${ }^{44}$

This should also explain the abundance of seemingly unnecessary details in Lost in the Funhouse or Barthelme's short stories. The minute elaboration of these details serves to heighten the realistic illusion, but this only makes the effect more striking when the fictitiousness of the same details is exposed a moment later. In Concerning the Bodyguard, for example, the otherwise realistic and plausible details taken from the 'life' of the bodyguard are immediately undermined by the question marks: "Does the bodyguard know which sections of the National Bank's yearly report on debt service have been falsified?... Does the bodyguard patronise a restaurant called The Crocodile?" 45

The same effect is produced by the description of a certain object in too much detail. The amount of information supplied about the fictional object does not correspond to the significance of the role this object is supposed to play in the fictional world.

\begin{abstract}
... a Toby jug, not one of those garish-coloured monstrosities of Victorian manufacture, but a delicate little thing in pale mauve and primrose yellow, the jolly man's features charmingly lacquered by a soft blue glaze (ceramic experts may recognise a Ralph Wood)... the Toby was cracked, and was to be re-cracked in the course of time, as I can testify, having bought it myself a year or two ago for a good deal more than the three pennies Sarah was charged ... ${ }^{46}$
\end{abstract}

The 'Toby jug' is described too accurately in comparison to its marginal function in advancing the narrative. The minuteness of the description heightens the

${ }^{44} L i F$, p. 76

${ }^{45}$ D. Barthelme: "Concerning the Bodyguard." in: Forty Stories. p. 48

${ }^{46} F L W$, p. 268 
illusion of reality to an extent that while the reader may indeed find the existence of the described object plausible, he or she is at the same time forced to acknowledge the inherently deceptive nature of fictional representation. In addition, the elaborate description of the 'Toby jug' is in the following undermined by the direct intrusion of the author - incidentally, a good example of the combination of an overt metafictional strategy (authorial intrusion into the fictional world) with a covert metafictional strategy (describing a fictional object in unnecessary detail). By presenting the same 'Toby jug' as a fictional object and a real object,

Fowles employs the [realist] convention against itself. The effect of this, instead of reinforcing our sense of a continuous reality, is to split it open, to expose the levels of illusion. We are forced to recall that our 'real' world can never be the 'real' world of the novel. ${ }^{47}$

This effect may be further intensified by inserting entirely unexplained details and contingent information into the narrative. At one point in Barthelme's interminable sentence, the reader suddenly comes across the following greeting inserted between two self-reflective comments on the sentence itself:

but of course it is not that query that this infected sentence has set out to answer (and hello! to our girlfriend, Rosetta Stone, who has stuck by us through thin and thin) but some other query that we shall some day discover the nature of... ${ }^{48}$

It may be objected that realist fictions also contain countless examples of seemingly random details, one only has to think of Princess Bolkonskaya's famous moustache in Tolstoy's War and Peace. Such apparently contingent details are always meant, however, to increase the illusion of the autonomy of the represented fictional world. By contrast, over-determined, contingent and unnecessarily elaborate details have a diametrically opposite function in postmodern fiction. They are used to destroy the independence and plausibility of the fictional world by producing a deliberately exaggerated, and therefore subversive, hyperrealistic effect.

\footnotetext{
${ }^{47}$ P. Waugh: Metafiction. p. 33

${ }^{48}$ D. Barthelme: "Sentence." in: Forty Stories. p. 163
} 
This strategy may be carried to a point where fiction becomes a series of miniature narrative segments only connected by an arbitrary motif. In Barthelme's On the Deck, for instance, the meticulously described details are only spatially related to one another - they are all 'on the deck'. The story resembles a trompe-l'œil, but one in which the illusional character of what is presented is continuously foregrounded by the fact that the pieces constituting the trompe-l'ail seem to have been thrown together perfectly at random. A similar strategy is used in The Flights of Pigeons from the Palace, where the general motif giving coherence to the individual narrative segments is merely the series of fantastic performances in a palazzo, so "...the mimetic framework that might serve to motivate the clash of discourses realistically has been reduced to the absolute minimum." ${ }^{49}$ These strategies are radically different from those used in constructing the fictional world of realist narratives. Realist strategies are aimed to increase the coherence of the fictional world by establishing as many causal and hierarchical links as possible between the fictional objects constituting it. Postmodern strategies reduce the connection between isolated narrative segments to a merely spatial, chronological, or even completely accidental relationship.

The strategies enumerated thus far in the present section experiment with possible ways of linking narrative segments to one another. Structural innovations, however, can also be applied to the general organisation of the fictional text. ${ }^{50}$ The works discussed here offer paradigmatic examples of such structural innovations: The French Lieutenant's Woman contains three alternative endings and Lost in the Funhouse is a typical labyrinth story. In Barthelme's short stories, one comes across various kinds of mise-en-abyme, 'chinese-box' and other characteristically postmodern structures.

These structural inventions are of considerable interest in their own right because they develop new ways of structuring fictional texts. Nevertheless, it is even more remarkable that, together with other innovative strategies, they stand for a new approach to mimesis and verisimilitude in fictional representation. They can be characterised as (covertly) metafictional structural techniques, since they serve to highlight the fictionality of literary texts. They foreground the opposition of representing and represented. At the same time, they demonstrate

\footnotetext{
${ }^{49}$ B. McHale: Postmodernist Fiction. p. 169

${ }^{50} \mathrm{~B}$. McHale offers an exhaustive list of structural innovations in postmodern fiction. Ibid, pp. 106 . 130
} 
that the ostentatious display of this contradiction does not necessarily entail a pessimistic view of the mimetic potential of postmodernist fiction. Just as all other innovative metafictional and transtextual strategies in postmodern fiction, these structural innovations are not only used to criticise traditional realistic forms, but also to explore new possibilities of mimetic representation.

Consider the function of the three alternative endings in The French Lieutenant's Woman. The first ending does not trespass the boundaries of the diegetic world, being subsequently explained away as the dream of the protagonist. By contrast, the second bifurcation already involves a metafictional frame-breaking. A 'happy end' and a 'tragic end' are subsequently presented as alternative conclusions of the same story. This bifurcation is not motivated at the level of the story, i.e. there is nothing in the plot itself that could justify this impossibility. After the 'happy end', Fowles returns once again to the point of bifurcation, and now offers the 'tragic end'. This involves, of course, a massive violation of the hypothetical autonomy of the fictional world. ${ }^{51}$

At first sight, Fowles' strategy of presenting alternative endings of the same story may seem outright anti-realistic. Logic tells us that a proposition and its contradiction cannot both be true, and indeed traditional realist fictions tend to respect the principle of the excluded middle, otherwise they would seriously decrease the plausibility of their fictional worlds. Yet the French Lieutenant's Woman may be an anti-realist novel if realism is understood as a specific period in the history of fiction, but it is certainly not an a-realist novel if realism is meant to imply a belief in the descriptive and representative potential of fiction. Fowles does not question the assumption that it is possible to establish true and meaningful correspondences between the represented fictional world and 'our' 'non-fictional' 'world'. The validity of the principle of the excluded middle as well as other basic principles of a 'traditional' logic may be suspended for the time being, but the world of Fowles' novel still remains 'similar' to 'our world' in fundamental ways.

What is more, precisely because the principle of the excluded middle and other basic logical tenets are deliberately ignored, the fictional world of the French Lieutenant's Woman can be highly relevant to the contemporary reader. Realism is not discarded, but transposed to another domain of the literary work. The most

\footnotetext{
${ }^{51}$ It is interesting that this intervention at the narrative level is coupled with the authorial intrusion at the level of the story already discussed in section 2.2.1. Another example of the combination of an explicit and implicit metafictional strategy.
} 
important themes of the French Lieutenant's Woman are concerned with various aspects of human freedom. To what extent are human decisions free? How far are these decisions determined by the prevailing morality and prejudices of an age? Can such limitations be transcended through love? What authenticates Fowles' treatment of these questions is his use of innovative strategies. By arrogantly encroaching upon the freedom of his characters, Fowles reflects the sense of impotence felt by the (post)modern individual in face of the enormous pressure exerted on him or her by personal, social and political networks. By emphasising the "ineluctable writtenness of character," his ignorance of Sarah's innermost motives, on the other, he gives a faithful account of the post(modern) ambiguity with regard to the human psyche - the working of which is supposed to be describable in terms of scientific laws, and is found again and again to be irreducible to any final explanation. Ostentatiously flaunting the moment when the fate of his protagonist is decided by the toss of a coin ("I take my purse from the pocket of my frock-coat, I extract a florin, I rest it on my thumbnail, I flick it... So be it..."), ${ }^{53}$ he reflects the (post)modern understanding of human destiny as a series of contingent events. The contingency and seeming alogicality of the novel's structure represents, therefore, a (post)modern reality that is itself contingent and alogical.

In a short story about Ocean City, Maryland, during World War II, the author could make use of the image of sailors on leave in the penny arcades and shooting galleries, sighting through the crosshairs of toy machine guns at swastika'd subs, while out in the black Atlantic a Uboat skipper squints through his periscope at real ships outlined by the glow of penny arcades. ${ }^{54}$

This notion of transposed realism can also be applied to the works of Barth and Barthelme. Lost in the Funhouse flagrantly repudiates and ridicules obsolete conventions of realist fiction. Yet exactly the labyrinth structure of the story created through innumerable jumps of the narrative backwards and forwards as well as abrupt juxtapositions of incongruous narrative segments - directs the readers' attention to central themes of the story. Form and content stand in a most 'realistic' unity: the 'funhouse' becomes both the key metaphor and the

\footnotetext{
${ }^{52}$ B. McHale: Postmodernist Fiction. p. 105

${ }^{53}$ FLW, p. 390

${ }^{54} L i F$, p. 86
} 
underlying structural principle of Barth's short story. Through the use of innovative narrative strategies, Ambrose's identity crisis and complexes, his wavering between daydreams, sexual fantasies and accurate observations acquire a much deeper meaning. They are made to stand for such pre-eminent post(modern) concerns as the increasingly blurred boundary between reality and fiction, the irresolvable antagonism of growing reflectiveness and the longing for immediacy, and so on.

In his Sentence, Barthelme offers an even more radical example of the symmetry of form and content. "Barthelme's story Sentence (City Life) sets out to be a sentence, to show what a sentence can do. It shows how a sentence can be a clause within a clause within a clause which has at its centre a story, "The Fantastic Orange Tree', composed of sentences which..." ${ }^{55}$ Form and content become interchangeable labels: Sentence is a sentence about a sentence. The metaphors developed within this sentence appear to have an independent and gratuitous existence, or in Brian McHale's words, they "take off" and have a "liveliness of their own." It is deliberately made difficult for the reader to establish an overall frame of reference through which the microscopic worlds of these metaphors could be related to a non-linguistic reality. The text is on the verge of becoming a purely self-contained linguistic continuity, it resembles an elaborately embellished two-dimensional surfac $\epsilon$.

In short, hardly could a text be more antagonistic to traditional realism Yet exactly by developing a self-contained linguistic continuity Barthelme can say something new about how fictional representation tries to capture the will-o'-the wisp of reality. A frustrating and unending pursuit, resembling that of swif: Achilles after the inert tortoise in Zeno's paradox. No matter how refined fictional representation becomes, suggests Barthelme, it will never leap over it: own shadow, remaining the representation and construction of reality in anci through its own textuality, never becoming immediate reality itself:

...a disappointment, to be sure, but it reminds us that the sentence itsel is a man-made object, not the one we wanted of course, but still a construction of man, a structure to be treasured for its weakness, as opposed to the strength of stones. ${ }^{57}$

${ }^{55}$ P. Waugh: Metafiction. p. 142

${ }^{56}$ B. McHale: Postmodernist Fiction. p. 138

${ }^{57}$ D. Barthelme: “Sentence." in: Forty Stories. p. $16 ?$ 


\subsubsection{Linguistic strategies}

It has been mentioned previously that the separation of (covertly transtextual) linguistic strategies from (covertly metafictional) structural strategies necessarily involves a degree of theoretical arbitrariness. In fact, Barthelme's Sentence clearly shows that these strategies almost always operate in combination in the actual texts. This is the reason why much that belongs to this section has already been discussed above. I will now concentrate, therefore, on a single text, Barthelme's On the Deck, to consider how innovative narrative strategies manifest themselves in the language of postmodern fictions. At issue is whether linguistic strategies can indeed be seen as radical, though implicit, counterparts of overtly transtextual strategies. More generally, such radical examples of postmodern innovation as Barthelme's text may also reveal more about the relationship of representing word and represented world in postmodern literature.

Many would characterise On the Deck as a completely anti-mimetic text, being one of "those fictions that, in rejecting realism more thoroughly, posit the world as a fabrication of competing semiotic systems which never correspond to material conditions". ${ }^{58}$ Indeed, Barthelme employs several highly unconventional linguistic strategies in order to prevent the reader from putting together a coherent mimetic framework. Although individual narrative segments are realistically described, when placed side by side they do not constitute a possible world. Obviously, it would be extremely difficult to interpret the text realistically, associating its 'imaginatively constructed fictional objects with a general class of possible real objects'. Moreover, On the Deck cannot even be read as a fabulation or a fairy tale. What the text (re)presents is neither our world nor is it a fantastic world with a logic different from ours, but still with an internal consistency of its own. Radical metafictional (structural) and transtextual (linguistic) narrative strategies are deliberately exploited in a way that makes a final contextualisation of the narrative segments impossible.

Having long catered to the objectives of fictional representation most obediently, now the language of fiction assumes its independence and actively subverts the possible development of a fictional world. Instead of flowing smoothly to help concentrate the reader's attention on what is happening or what is described, the language of the text distracts us with an aggressive persistency from our attempts at 'making sense of it all'. Textual fluency is systematically undermined through disruptions of various kinds: repetitions, conspicuous

\footnotetext{
${ }^{58}$ P. Waugh: Metafiction. p. 19
} 
typographical devices, obtrusive lexical items, deliberately clumsy sentences, and finally even through an abrupt change of focalisation. ${ }^{59}$

Take, for instance, the obstinate repetition of colours. The waves are grey, the lion in the cage is dirty yellow-brown, the captain is a "red-faced man in a blue blazer", and so on. There are altogether nineteen references to colour in a text two-and-a-half pages long. By flagrantly over-emphasising a minor descriptive element, which is normally supposed to increase the realistic effect, the reader's attention is diverted from the object described to the descriptive element itself. The rhythm of the recurring adjectives becomes more important than what they describe. The repetition of the same word, a strategy much cherished by Barthelme, works to the same effect: "a young woman with a black hair in a thin thin yellow dress" ${ }^{60}$ or "The dog is afraid of the lion, keeps looking back over his shoulder at the lion" ${ }^{\prime 11}$ [my italics].

The vocabulary of On the Deck is strongly characterised by what Brian $\mathrm{McHale}$ calls lexical exhibitionism. ${ }^{62}$ Consider references to the pick-up car parked on the deck as "Camry", to the barbecue as "hibachi", or to "PRISMATEX", the label on the "yellow fifty-five-gallon drum", all taken from a technical jargon. In contrast to this, the text may suddenly switch to an eloquent register in phrases such as "The captain kisses the hem of the young woman's yellow dress" ${ }^{\text {"3 }}$ and "The wicker exclaimed as your weight fell upon me"64 [my italics]. The effect of such unexpected lexical items may get further emphasis through alliteration: "The basin is full of brown blood, brown-stained blooms of gauze," and "HONK IF YOU LOVE JESUS" both capitalised, "Smithsonian" in italics.

Nevertheless, the most striking evidence of the destructive utilisation of language against fictional constructions is provided by Barthelme's peculiar sentence-structures: "the construction of sentences so awkward (to the point of ungrammaticality) that it is the sentence-structure itself that fixes the attention,

\footnotetext{
${ }^{59}$ For a theoretical definition of focalisation, see G. Genette: Narrative Discourse. pp. 189-194

${ }^{60}$ D. Barthelme: "On the Deck." in: Forty Stories. p. 15

${ }^{61}$ Ibid, p. 15

${ }^{62}$ "Lexical exhibitionism involves introducing words which are by their very nature highly conspicuous, self-foregrounding as it were: rare, pedantic, archaic, neologistic, technical, foreign words." in: McHale: Postmodernist Fiction. p. 151

${ }^{63}$ D. Barthelme: "On the Deck." in: Forty Stories. p. 15

${ }^{64}$ Ibid, p. 16

${ }^{65}$ Ibid, p. 15
} 
distracting us from whatever content the structure may carry". ${ }^{66}$ A few examples: "There is someone inside the car, behind the wheel. This person is named Mitch."; "The tilting of the deck increases; spray." ${ }^{68}$ and "There's a bucket of raw liver between his knees, liver for the lion, he's up to his elbows in liver. ${ }^{n 69}$ Once again, one gets the impression that Barthelme was more interested in these structures themselves, their creative awkwardness, their rhythmic effect and their "sludge quality" than in what they are actually supposed to describe. "It's an itself if it's successful..."

On the Deck does not have a world, it only has a relief-like surface. The strategies discussed above are combined with metafictional strategies to produce a trompe-l'oeil, or even better, a pop-up picture, containing cut-out figures and objects that rise up when the page is turned. Several explicit comments scattered in the text reinforce this relief or 'pop-up' effect. Consider "Next to but not touching the lion, members of a Christian motorcycle gang," "To the right of the Christian bikers and a bit closer to the coils of razor forward of the lion is a parked Camry (in profile)," "Next, a shuffleboard court and two men..." ${ }^{74}$ [my italics] - the camera moves left to right and back, zooms in and out to focus on various parts of the picture, and then it even gives us two full 'stills': "Winter on deck. All of the above covered with snow. Christmas music" and "Then, spring. A weak sun, then a stronger sun. ${ }^{75}$

Finally, the abrupt change from third-person to first-person singular at the end questions the status of the preceding text as a whole. It is suggested that the man "sitting in a red wicker chair" is the same person as the 'I' of the last paragraph: "You came and fell upon me, I was sitting in the wicker chair," we cannot be sure. The unresolved tension between the homodiegetic and

\footnotetext{
${ }^{66}$ B. McHale: Postmodernist Fiction. p. 154

${ }^{67}$ D. Barthelme: “On the Deck." in: Forty Stories. pp. 14-15

${ }^{68}$ Ibid, p. 15

${ }^{69}$ Ibid, p. 16

${ }^{70}$ D. Barthelme: Snow White. p. 96

${ }^{71}$ Barthelme's own words in: J. D. Bellamy: The New Fiction: Interviews with Innovative American Writers. Chicago: Urbana. 1974. pp. 51-52. Quoted in: P. Waugh: Metafiction. p. 144

${ }^{72}$ D. Barthelme: “On the Deck." in: Forty Stories. p. 14

${ }^{73}$ Ibid, p. 14

${ }^{74}$ Ibid, p. 16

${ }^{75}$ Ibid, p. 16

${ }^{76}$ Ibid, p. 16
} 
heterodiegetic perspectives ${ }^{77}$ shows both the preceding 'relief' and the 'you' and 'I' of the last paragraph to be nothing more than linguistic constructs. The textuality of the text is systematically played off against the fictional illusion. "There can never be an escape from the prisonhouse of language." ${ }^{78}$ The fictional world is denied even the minimum degree of autonomy, the sign completely determines the signifier.

On the Deck represents, therefore, one of the most radical forms of postmodern transtextuality. Explicit transtextual practices in postmodern fiction exposed the textuality of literary works by having shown that fictional representation necessarily depends on the prevailing conventions and approved discourses of a literary period. Going even further, covert transtextual strategies, such as those in On the Deck, make the claim that fictional representation as such is merely a function of the textuality of the text. Ultimately, every con-text is only another text. The represented world is shattered into pieces that cannot be put together. What remains are the 'words on the page.'

\section{CONCLUSION}

"These adventurers of the psyche, called writers, go to the very end of the darkness where our relationships no longer dare venture forth"

\subsection{Realism and authenticity}

Why should we be interested in these 'words on the page'? Why should this postmodern literature of 'non-sense', this endless mumbling of linguistic 'dreck' have any relevance to our, often much too common-sense lives? Why should anyone - apart from literary critics and university students in search of a suitable topic for a seminar paper - feel the need to listen to authors theorising about their fiction?

the fact is that people still lead lives, mean and bleak and brief as they are... people still fall in love... and what goes on between them is still not only the most interesting but the most important thing in the bloody murderous world, pardon the adjectives. And that my dear is what

\footnotetext{
${ }^{77}$ see G. Genette: Narrative Discourse. pp. 244-245

${ }^{78}$ P. Waugh: Metafiction. p. 53

${ }^{79}$ J. Kristeva: Tales of Love. New York: Columbia University Press. 1987. p. 380
} 
writers have got to find ways to write about in this adjective adjective hour of the ditto ditto same noun as above... ${ }^{80}$

Yet postmodern fictions are not theories of fiction in a narrative form. Their excessive self-reflexivity and ubiquitous irony, their indulgence in a selfdestructive inferiority complex and their outbursts of arrogance are all symptoms, means to an end.

Postmodern fictions challenge the conventions and norms of realist (and modernist) writing through explicit and implicit forms of critique and subversion. They examine, analyse and dissect. Traditional narrative techniques and topoi are exposed as carefully designed parts of a discursive and rhetorical machinery. These traditional figures are treated in a parodic and critical fashion because their use can no longer guarantee the authenticity of the literary work. This, however, does not mean that the problem of authenticity per se would have become irrelevant in postmodern literature. On the contrary, it is exactly the characteristically postmodern search for authentic forms of expression that dictates this critical attitude. Postmodern fictions become introverted, meditative, critical and ironic, reflecting the general epistemological insecurity of postmodernity. In order to refute the charge of inauthenticity, they constantly have to justify, verify, confirm, validate, authenticate, legitimise their way of describing the world.

"The Real cannot be articulated as such." ${ }^{\prime 1}$ The epistemological uneasiness of postmodernity is coupled with an ontological insecurity. Two sides of a coin. Reality itself falls victim to the interminable process of deconstruction and analysis. It is also shown to be an elaborate construct, a network of conventions, institutions and traditions. The authenticity of fictional representation can no longer be guaranteed through the correspondence of the fictional object to a 'general class of possible real objects'. Real objects prove to be no less a result of a construction procedure than fictional objects. Reality is fictionalised and fiction is real-ised. If reality ceases to be experienced as a hierarchical world-order governed by unchanging ontological laws, then this change has to be reflected in the aesthetics of fictional representation as well. If reality can no longer be comprehended as a cohesive unity, then fictional representation will also have to let go of the illusion of totality.

${ }^{80} \mathrm{~J}$. Barth: "Title". in: Lost in the Funhouse. p. 113

${ }^{81}$ J. Kristeva: Tales of Love. p. 378 
Yet realism is not discarded, but only transposed to other levels of the literary work. When the world outside is perceived to have been atomised into disjunctive and self-contained ontological domains, then fictional representation can only remain authentic if it also becomes self-contained and incoherent. If these ontological domains seem to carry an ever increasing burden of selfreflexivity, then fictional representation is also to show a growing awareness of its fictional status.

Postmodern fictions ostentatiously admit to being part of just another self-contained language-game in the inexhaustible plurality of postmodern language-games: innovative narrative strategies loudly proclaim the contingency, superficiality, fictionality and textuality of contemporary literary works. It is precisely the ability to do so, "to turn ultimacy against itself" ${ }^{82}$ that distinguishes postmodern fiction from other language-games. Postmodern fictions guarantee their own legitimacy by demonstrating that even if traditional forms of realism are consequently rejected, it is possible to preserve the immanent authenticity of fictional representation. This paradoxical ability of finding authentic forms to represent a non-imitable, anti-mimetic non-reality is the real source of postmodern innovation.

\section{BIBLIOGRAPHY}

Barth, John: Lost in the Funhouse. New York: Doubleday. 1988.

Barthelme, Donald: Forty Stories. New York: G. P. Putnam \& Sons. 1987.

Barthelme, Donald: Snow White. New York: Atheneum. 1982.

Fowles, John: The French Lieutenant's Woman. London: Jonathan Cape. 1978.

Barth, John: "The Literature of Exhaustion." Atlantic 220 (August 1967), pp. 2934.

Genette, Gérard: Narrative Discourse. Oxford: Basil Blackwell. 1980.

Genette, Gérard: Palimpseste. Die Literature auf zweiter Stufe. Frankfurt a. M.: Suhrkamp. 1993.

${ }^{82} \mathrm{~J}$. Barth: "Title". in: Lost in the Funhouse. p. 109 
Habermas, Jürgen: The Philosophical Discourse of Modernity. Twelve Lectures. Cambridge: Polity Press. 1994.

Hinden, Michael: "Lost in the Funhouse: Barth's Use of the Recent Past." in: Joseph J. Waldmeir, ed.: Critical Essays on John Barth. Boston: G. K. Hall \& Co. 1980. p. 191.

Knapp, Edgar H.: "Found in the Barthhouse: Novelist as Savior." in: Joseph J. Waldmeir, ed.: Critical Essays on John Barth. Boston: G. K. Hall \& Co. 1980. p. 170.

Kristeva, Julia: Tales of Love. New York: Columbia University Press. 1987.

Lukács, György: A heidelbergi mûvészetfillozófia és esztétika. Budapest: Magvetõ. 1975.

Luzen, Sarah E.: "Notes on Metafiction: Every Essay Has a Title." in: Larry McCaffery, ed.: Postmodern Fiction: A Bio-Bibliographical Guide. London: Greenwood Press. 1986. pp. 93-116.

Lyotard, Jean-François: "Answering the Question: What is Postmodernism?" in: The Postmodern Condition. A Report on Knowledge. Manchester: Manchester University Press. 1992. pp. 70-82 (appendix).

Lyotard. Jean-François: The Postmodern Explained. Correspondence 1982-1985. Minneapolis, London: University of Minnesota Press. 1993.

McHale, Brian: Postmodernist Fiction. New York: Methuen. 1987.

Waugh, Patricia: Metafiction. London: Methuen. 1984. 